\title{
Adaptifitas dan Analisis Pengaruh Antar Komponen terhadap Hasil Padi Varietas Unggul Baru Padi Sawah Irigasi
}

Apresus Sinaga ${ }^{1}$, Junita Br. Nambela ${ }^{1 *}$

${ }^{1}$ Balai Pengkajian Teknologi Pertanian Papua Barat

\section{ARTIKEL INFO}

Sejarah artikel

Diterima 16/11/2020

Diterima dalam bentuk revisi 02/12/2020

Diterima dan disetujui 04/12/2020

Tersedia online 23/12/2020

\section{Kata kunci}

Komponen variabel

Analisis regresi berganda

Produksi gabah
ABSTRAK

Penggunaan vareitas unggul baru yang adaptif merupakan salah satu faktor penting untuk meningkatkan produktivitas padi. Varietas unggul diketahui berkontribusi besar terhadap peningkatan produksi padi sebesar lebih dari 50\%. Penelitian ini bertujuan untuk mengetahui penampilan dan melihat hubungan antar karakter komponen tanaman terhadap karakter hasil dengan analisis regresi dan melihat hasil potensial varietas unggul baru padi yang adaptif. Penelitian dilaksanakan di Kabupaten Manokwari pada bulan Januari Desember 2013. Luasan masing-masing lokasi penelitian sebesar 0,25 ha. Penelitian disusun dengan menggunakan Rancangan Acak Kelompok (RAK) dengan tiga varietas sebagai perlakuan dan 3 tempat sebagai perlakuan. Variabel agronomi yang diamati meliputi tinggi tanaman, jumlah anakan produktif dan hasil gabah. Data pengamatan dianalisis menggunakan analisis varian (Anova) pada taraf 5\%, apabila terdapat hasil beda nyata maka dilakukan uji lanjutan dengan Duncan's Mutiple Range Test (DMRT), untuk mengetahui besarnya pengaruh masing-masing faktor tinggi tanaman dan jumlah anakan (variabel independent) tersebut terhadap hasil produksi (variabel dependent) digunakan analisis regresi berganda dengan fasilitas automatic linear modeling. Hasil penelitian menunjukkan terdapat perbedaan yang signifikan jumlah anakan produktif inpari 20 dan inpari 18 terhadap inpari 16 antar varietas sedangkan jumlah tinggi tanaman dan hasil gabah tidak menunjukkan perbedaan yang nyata pada semua varietas. Tingkat pengaruh (importenace) variabel tinggi dan jumlah anakan sebesar R2 $=67,9 \%$ dan R2 $=32,1 \%$ dari $15,5 \%$ (R2) total pengaruh kedua variabel terhadap hasil gabah padi. 


\section{ABSTRACT}

The use of new, adaptive superior varieties is an important factor to increase rice productivity. Superior varieties are known to have contributed greatly to the increase in rice production by more than 50\%. This study aims to determine the appearance and see the relationship between the character of plant components to the yield character with regression analysis and to see the potential yield of new adaptive varieties of rice. The research was conducted in Manokwari Regency from January to December 2013. The area of each study location is 0.25 ha. The study was compiled using a Randomized Block Design (RBD) with three varieties as treatment and 3 places as treatment. The agronomic variables observed included plant height, number of productive tillers and grain yield. Observation data were analyzed using analysis of variance (Anova) at the 5\% level, if there were

\section{PENDAHULUAN}

Beras merupakan bahan pangan pokok bagi masyarakat sebagai sumber karbohidrat dan kalori utama secara nasional (Asnawi, 2013). Peningkatan jumlah penduduk dengan pertumbuhan yang masih cukup tinggi telah memunculkan kekhawatiran akan terjadinya kerawanan pangan di Indonesia (Pramono et al., 2016).

Sudah banyak di beberapa daerah, areal pertanian beralih fungsi menjadi non pertanian dan akibat pengaruh globalisasi sehingga perkembangan sektor pertanian perlu terus dikembangkan agar semakin maju, efisien, tangguh serta terdapat keanekaragaman hasil pertanian (Margi dan Balkis, 2016). Peningkatan produksi pertanian dapat dilaksanakan melalui usaha diversifikasi, intensifikasi, ekstensifikasi dan rehabilitasi lahan pertanian dengan mengembangkan dan memanfaatkan ilmu pengetahuan dan teknologi (Sumodiningrat, 2000). Produksi padi dapat ditingkatkan dengan cara mengoptimalkan input produksi melalui perbaikan teknologi significant differences, a further test was carried out with the Duncan's M Quotle Range Test (DMRT), to determine the magnitude of the influence of each factor on plant height and number of tillers (independent variables) To the production result (dependent variable), multiple regression analysis is used with automatic linear modeling facility. The results showed that there was a significant difference in the number of productive tillers inpari 20 and inpari 18 against inpari 16 between varieties, while the number of plant height and grain yield did not show significant differences in all varieties. The level of influence (importenace) variable is high and the number of tillers is $R 2=67.9 \%$ and $R 2=32.1 \%$ from $15.5 \%(R 2)$ the total effect of the two variables on the yield of rice grain.

budidaya, baik penggunaan pupuk, penggunaan benih, ketersediaan tenaga kerja, dalam meningkatkan produktivitas (Rumintjap dan Muis, 2014).

Hasil produktivitas padi dapat ditingkatkan jika teknologi yang digunakan tepat guna (Damiri et al., 2015). Penggunaan benih unggul berlabel, pemupukan berimbang dan sesuai dengan rekomendasi dan penanaman dengan jajar legowo dapat meningkatkan produksi dan pendapatan usaha tani padi sawah (Asnawi, 2014). Giamerti dan Yursak (2013) menyatakan sistem tanam jajar legowo dapat meningkatkan produksi padi karena memanfaatkan efek tanaman pinggir selalu memiliki hasil yang lebih banyak dan lebih mudah dalam perawatan pengendalian hama penyakit dan pemupukan.

Varietas sebagai salah satu komponen produksi telah memberikan sumbangan sebesar 56\% peningkatan produksi padi mencapai hampir tiga kali lipat (Senewe dan Alfons, 2011). Penanaman padi menggunakan varietas unggul baru (VUB) dapat meningkatkan produksi padi sehingga meningkatkan 
antusiasme petani dan pemulia untuk menghasilkan VUB baru (Kartina et al., 2016). Varietas unggul sangat berkontribusi terhadap peningkatan produksi padi dan telah terbukti nyata melalui keberhasilan pencapaian swasembada beras pada tahun 1984 (Suhendrata, 2010). Varietas unggul baru dapat diadopsi petani jika telah diketahui karakteristik kualitas dan hasil padi sawah yang penting bagi preferensi petani seperti daya hasil, ketahanan hama dan penyakit, tekstur nasi, kemudahan panen, umur panen, jumlah anakan, tinggi tanaman, serta panjang malai (Heni, 2012).

Varietas unggul baru merupakan salah satu faktor penting untuk dapat meningkatkan produksi padi yang adaptif dan spesifik lokasi. Oleh karena itu perlu dilakukan penelitian lebih lanjut untuk mengetahui penampilan dan melihat hubungan antar karakter komponen tanaman terhadap karakter hasil dengan analisis regresi dan melihat hasil potensial varietas unggul baru padi yang adaptif.

\section{BAHAN DAN METODE}

Penelitian dilakukan pada lahan sawah irigasi teknis di Distrik Prafi, Kabupaten Manokwari, Provinsi Papua Barat pada bulan Januari hingga Desember 2013.

Adapun bahan penelitian ini antara lain: benih padi varietas Inpari-15, Inpari-16, dan Inpari-18. Pupuk Urea, SP-36 dan Phonska. Alat yang digunakan adalah bajak, caplak, cangkul, garuk, sabit, meter rol, terpal, karung, timbangan, mesin perontok dan alat tulis menulis.

Metode penelitian menggunakan Rancangan Acak Kelompok (RAK) dengan tiga varietas sebagai perlakuan dan tiga lokasi sebagai perlakuan.

Komponen tenologi yang diaplikasikan pada kegiatan pengkajian meliputi penggunaan benih berlabel (benih pokok), sistem tanam legowo 4:1, umur benih >18-20 hst, jumlah benih 2-3 perlubang tanam, dosis pupuk berdasarkan hasil uji tanah (PUTS), panen pada saat benih menguning $90 \%$ dan pasca panen menggunakan alat perontok dan penjemuran gabah dengan kadar air 12-14\%.

Pengolahan tanah dilakukan menggunakan hand tractor sebanyak 2 kali. Umur bibit pindah dari persemaian kelapangan berkisar 18-10 hari setelah tanam (HST). Penanaman dilakukan dengan sistem tanam jajar legowo 4:1 (40 cm x $\{20 \times 10\} \mathrm{cm})$. Jumlah bibit tanam per lubang sebanyak 1-3 tanaman, apabila tanaman ada yang mati atau pertumbuhan tanaman tidak normal maka dilakukan penyulaman paling lama 2 minggu setelah tanam (MST). Pemupukan tanaman dilaksanakan sebanyak 2 kali. Pemupukan pertama (takaran pupuk dasar), urea dan $\mathrm{KCl}$ diberikan setengah bagian dari seluruhnya sedangkan pupuk SP-36 diberikan seluruhnya sekaligus pada pemupukan dasar. Pupuk susulan urea dan $\mathrm{KCl}$ diberikan pada saat tanaman sudah berumur 35-50 HST. Pemberian pupuk dilakukan dengan cara disebar diantara barisan tanaman. Penyiangan gulma dilakukan dengan cara mekanik dan kimia. Pengendalian hama dan penyakit menggunakan insektisida anjuran dengan tepat jenis, tepat dosis, tepat waktu dan tepat sasaran.

$$
\text { Pengamatan dilakukan terhadap } 3
$$
tanaman sampel per plot percobaan yang 
diulang sebanyak 3 kali sehingga terdapat 9 sampel. Komponen pertumbuhan yang diamati adalah tinggi tanaman, dan jumlah anakan sedangkan komponen hasil yang diamati meliputi hasil ubinan per petak $2 \mathrm{~m} \times 3 \mathrm{~m}$.

Data pengamatan yang di didapat, dianalisis dengan menggunakan analisis varian (Anova) pada taraf $5 \%$, apabila terdapat hasil beda nyata maka dilakukan uji lanjutan dengan Duncan's Mutiple Range Test (DMRT) 5\%. Untuk lebih mengetahui besarnya pengaruh masing-masing faktor tinggi tanaman dan jumlah anakan (variabel independen) tersebut terhadap hasil produksi (dependen) digunakan analisis regresi berganda dengan fasilitas automatic linear modeling pada SPSS 23 (Santoso, 2016).

\section{HASIL DAN PEMBAHASAN}

\section{Tinggi Tanaman dan Jumlah Anakan}

Hasil analisis menunjukkan, tinggi tanaman tiga varietas tidak terdapat perbedaan yang siginifikan di semua ulangan, rata-rata tinggi tanaman yang tertinggi terdapata pada varietas Inpari 16 setinggi $96,11 \mathrm{~cm}$ diikuti varietas Inpari 20 setinggi $93,33 \mathrm{~cm}$ dan terendah varietas Inpari 20 setinggi $88,22 \mathrm{~cm}$ (Tabel 1).

Terdapat perbedaan signifikan jumlah anakan Inpari 20 dan Inpari 18 terhadap jumlah anakan padi Inpari 16. Terdapat perbedaan signifikan jumlah anakan produktif antara Inpari 16 terhadap hasil anakan produktif inpari 18 (Hastini, et al., 2015)

Rata-rata jumlah anakan yang tertinggi adalah padi varietas Inpari 20 sebanyak 26 anakan, diikuti padi varietas Inpari 18 sebesar 23 anakan dan yang terendah pada padi varietas Inpari 16 sebesar 17 anakan. Rata-rata jumlah anakan varietas Inpari 20 meningkat sebesar $56,38 \%$ terhadap Inpari 16 sedangkan Inpari 18 meningkat sebesar 38,26\% terhadap Inpari 16.

Tabel 1. Rata-rata Tinggi Tanaman dan Jumlah Anakan Produktif

\begin{tabular}{cccccccc}
\hline \multirow{2}{*}{ No } & Perlakuan & \multicolumn{3}{c}{ Tinggi Tanaman } & \multicolumn{3}{c}{ Jumlah Anakan (buah) } \\
\cline { 3 - 7 } & & I & II & III & I & II & III \\
\hline 1 & Inpari 16 & 100,67 a & 93,00 a & 94,67 a & 18,33 b & $14,00 \mathrm{~b}$ & $17,33 \mathrm{~b}$ \\
\hline 2 & Inpari 18 & 83,00 a & 86,00 a & 95,67 a & 21,33 a & 23,00 a & 24,33 a \\
\hline 3 & Inpari 20 & 91,33 a & 94,00 a & 94,67 a & 25,33 a & 27,00 a & 25,33 a \\
\hline
\end{tabular}

Keterangan : Nilai diikuti huruf sama, tidak berbeda dengan DMRT 5\%

\section{Komponen Hasil}

Produksi gabah ubinan ketiga varietas padi tidak menunjukkan perbedaan yang signifikan antar varietas pada semua ulangan (Gambar 1). Hasil penelitian Zulhaedar dan
Mardiana (2016) mengatakan tidak terdapat perbedaan signifikan produksi padi antara Inpari 16, Inpari 22 dan Inpari 30 setelah diuji adaptasikan. 
Rata-rata hasil gabah tertinggi terdapat pada Inpari 20, diikuti Inpari 18 dan terendah varietas Inpari 16. Peningkatan hasil Inpari 20 sebesar 7,89\% dan inpari 18 sebesar 2,78\% terhadap hasil padi Inpari 16 (Gambar 1).

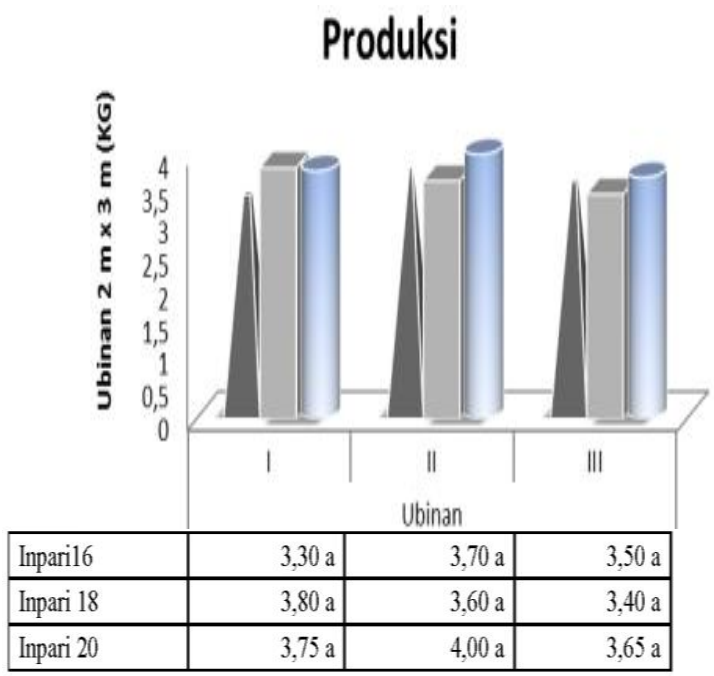

Gambar 1. Produksi Gabah Kering (kg) Padi

Varietas Inpari 16, Inpari 18 dan Inpari 20

Keterangan : Nilai diikuti huruf sama, tidak berbeda dengan DMRT 5\%.

\section{Hubungan Antar Komponen Pertumbuhan Terhadap Produksi Gabah}

Informasi kriteria model regresi terlihat sebesar -22,15 (Gambar 2). Pengaruh variabel tinggi tanaman dan jumlah anakan terhadap hasil gabah sebesar R2 $=15,5 \%$. Hal ini menunjukkan bahwa variabel tinggi tanaman dan jumlah anakan mempengaruhi hasil gabah sangat kecil sebab 84,5 \% hasil gabah dipengaruh oleh variabel lain.

Hasil uji Anova dalam bentuk grafik di bawah ini (Gambar 3) menunjukkan tidak erdapat pengaruh signifikan antara variabel tinggi tanaman dan jumlah anakan terhadap produksi gabah dimana efek pada model regresi paling besar terdapat pada variabel tinggi tanaman dan terendah variabel jumlah anakan (Gambar 3).

Model Summary

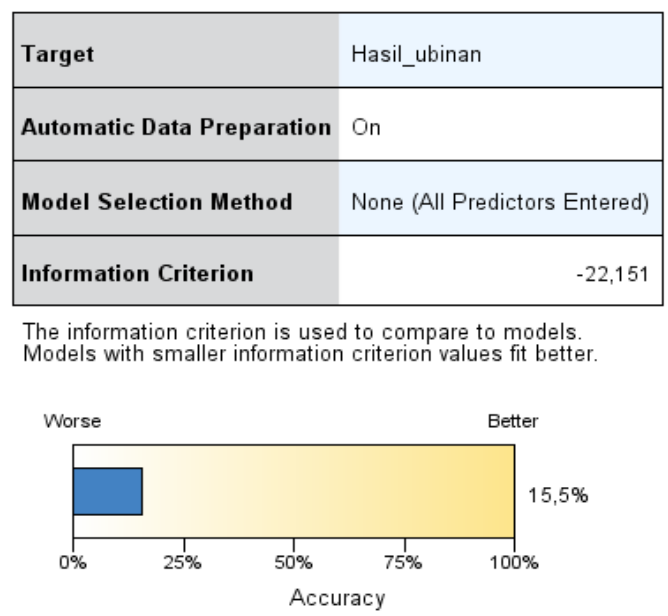

Gambar 2. Besaran Nilai Hubungan antara Variabel Independen dan Dependen (R2)

Hasil koefisien regresi tinggi tanaman dan jumlah anakan adalah sebesar -0,019 dan 0,016 dengan tingkat signifikansi sebesar 0,203 dan 0,364 (jauh diatas 0,05), tingkat pengaruh (inportenace) variabel tinggi dan jumlah anakan sebesar R2 $=67,9 \%$ dan 32,1 dari 15, 5\% (R2) total pengaruh kedua variabel terhadap hasil gabah padi (Gambar 3).

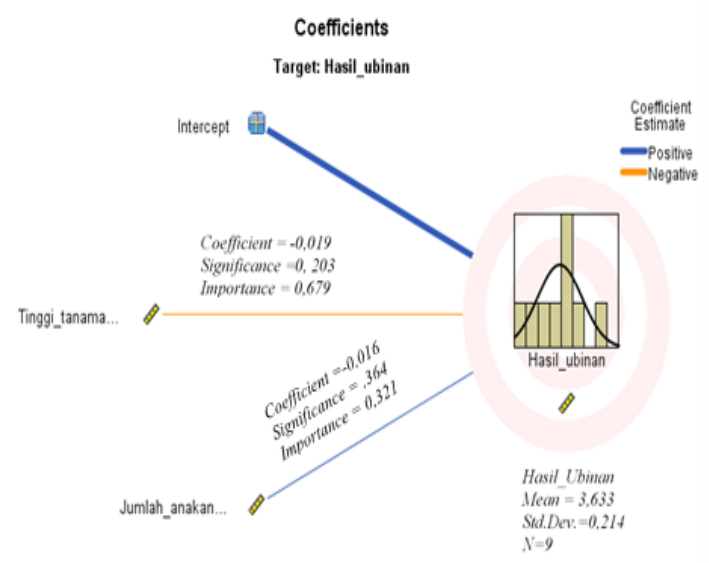

Gambar 3. Grafik Uji Koefisien Regresi Individu secara Visual pada Tingkat Signifikan 0,05 


\section{KESIMPULAN}

Terdapat perbedaan yang signifikan jumlah anakan produktif Inpari 20 dan Inpari 18 terhadap Inpari 16 antar varietas sedangkan jumlah tinggi tanaman dan hasil gabah tidak menunjukkan perbedaan yang nyata pada semua varietas. Tingkat pengaruh variabel tinggi dan jumlah anakan sebesar R2 $=67,9 \%$ dan $\mathrm{R} 2=32,1 \%$ dari $15,5 \%(\mathrm{R} 2)$ total pengaruh kedua variabel terhadap hasil gabah padi. Sehingga kesimpulannya tanaman padi varietas Inpari 20 lebih adaptif jika dibandingkan varietas Inpari 16 dan Inpari 18.

\section{UCAPAN TERIMA KASIH}

Penulis mengucapkan terima kasih kepada Kepala Balai dan rekan-rekan staff BPTP Balitbangtan Papua Barat yang telah membantu penelitian serta seluruh PPL yang terlibat dalam penelitian ini.

\section{DAFTAR PUSTAKA}

Asnawi, R. (2013). Analisis faktor-faktor yang mempengaruhi produksi padi sawah inbrida dan hibrida di Provinsi Lampung. Jurnal Sosial Ekonomi Pertanian Dan Agribisnis (SEPA), 10 (1), 11-18.

Asnawi, R. (2014). Peningkatan Produktivitas dan Pendapatan Petani Melalui Penerapan Model Pengelolaan Tanaman Terpadu Padi Sawah di Kabupaten Pesawaran, Lampung. Jurnal Penelitian Pertanian Terapan, 14 (1), 44-52.

Damiri, A., Oktavia, Y.Y. \& Firison, J. (2017). Uji Adaptasi Beberapa Varietas Unggul Baru (VUB) Padi Sawah di Kabupaten Bengkulu Utara Provinsi Bengkulu. Prosiding Seminar Nasional 2016 Membangun Pertanian Modern dan Inovatif Berkelanjutan Dalam Rangka Mendukung MEA, 342-348.

Giamerti, Y. \& Yursak, Z. (2013). Keragaan Komponen Hasil Dan Produktivitas Padi Sawah Varietas Inpari 13 Pada Berbagai
Sistem Tanam. Widyariset, 16 (3), 481488.

Hastini, T. R. I., Dan, D. \& Ishaq, I. (2015). Penampilan Agronomi 11 Varietas Unggul Baru Padi di Kabupaten Indramayu. Agrotrop: Journal on Agriculture Science, 4 (1), 73-81.

Heni S.P. Rahayu. (2012). Preferensi Petani Kabupaten Donggala terhadap Karakteristik Kualitas dan Hasil Beberapa Varietas Unggul Baru Padi Sawah. Widyariset 15 (2), 293-300.

Kartina, N., Wibowo, B. P., Widyastuti, Y., Rumanti, I. A., \& Satoto. (2016). Correlation and Path Analysis for Agronomic Traits in Hybrid Rice. Jurnal Ilmu Pertanian Indonesia, 21 (2), 76-83.

Pramono, J., Yuwono, D. M., \& Romdon, S. (2016). Keragaan Hasil Penerapan Komponen Pengelolaan Tanaman Terpadu pada Program Upaya Khusus Peningkatan Produksi Padi di Jawa Tengah (Studi Kasus di Wilayah Pantura Barat), 397-402.

Rumintjap, V. \& Muis, A. (2014). Padi Sawah di Desa Pandere Kecamatan Gumbasa Kabupaten Sigi Provinsi Sulawesi Tengah. e-Jurnal Agrotekbis 2 (3), 309316.

Santoso, S. (2016). Panduan Lengkap SPSS Versi 23. Jakarta: PT. Elex Media Komputindo.

Senewe, R.E. \& Alfons, J.B. (2011). Kajian Adaptasi Beberapa Varietas Unggul Baru Padi Sawah pada Provinsi Maluku. Jurnal Budidaya Pertanian 7 (2), 60-64.

Sumodiningrat. (2000). Pengantar Ilmu Pertanian. Jakarta: Raja Grafindo Persada.

Suhendrata, T. (2010). Uji Adaptasi Varietas Unggul dan Galur Harapan Padi Umur sangat Genjah pada Musim Kemarau dan Musim Hujan di Kabupaten Sragen, Jawa Tengah. Jurnal Ilmu Pertanian Indonesia, 15 (1), 1-6.

Tino M. \& Balkis, S. (2016). Analisis Pendapatan dan Efisiensi Usahatani Padi Sawah di Desa Kota Bangun Kecamatan Kota Bangun. Ziraa'ah, 41 (1), 72-77. 
Zulhaedar, F. \& Mardiana. (2016). Analisis Daya Saing Lada Hitam Di Kabupaten Lampung Timur. Prosiding Seminar Nasional Agroinovasi Spesifik Lokasi Untuk Ketahanan Pangan Pada Era Masyarakat Ekonomi ASEAN, 16041610 . 